https://doi.org/10.4314/ijs.v22i1.2

Ife Journal of Science vol. 22, no. 1 (2020)

\title{
AMINO ACIDS PROFILE OF CATFISH, CRAYFISH AND LARVA OF EDIBLE DUNG BEETLE
}

\author{
*Oriolowo, O. B., John O. J., Mohammed, U. B. and Joshua D. \\ Department of Biology, Federal College of Education P.M.B, Kontagora, Niger State, Nigeria \\ *Corresponding author's e-mail: oriolowotayo@yahoo.ca; Tel.: +2348032483295 \\ (Received: 16th November, 2018; Accepted: 11th November, 2019)
}

\section{ABSTRACT}

\begin{abstract}
Protein is an important nutrient for growth and development of humans and its quality depends on the types and composition of its amino acids. The amino acid profile of dung beetle larva was determined and compared with those of catfish and crayfish by HPLC using Applied PTH Biosystem amino acid analyzer. The data obtained were analyzed with inferential statistics of Analysis of Variance (ANOVA) and means separated using Least Significance Difference (LSD). The results showed that there were significant differences in the samples for all the set criteria for amino acid quality: total amino acid $\left(\mathrm{F}_{2,6}=219.9\right)$, percentage amino acid $\left(\mathrm{F}_{2,6}=1095.4\right)$, essential amino acid score $\left(\mathrm{F}_{2,6}=2588.4\right)$, essential to non-essential amino acid ratio $\left(\mathrm{F}_{2,6}=236.7\right)$ and predicted protein efficiency ratio $\left(\mathrm{F}_{2,6}=1049.4\right)$ all at $\mathrm{P}<0.05$. About $66.7 \%$ of the essential amino acids in dung beetle larva satisfy human nutritional requirement while amino acids like tryptophan, histidine and threonine were significantly higher in dung beetle. The amino acid score of this insect was higher as it has the potential of over $100 \%$ protein synthesis as against $68.2 \%$ and $80.9 \%$ respectively for catfish and crayfish. Moreover, a consumption of $46 \mathrm{~g}$ of dung beetle larva can effectively satisfy the daily human amino acid requirement. The study concluded that the protein quality of insects especially dung beetle larva compared favorably with commonly consumed human protein diets like catfish and crayfish. Therefore entomophagy should be encouraged in the face of the present dwindling availability of animal protein food sources.
\end{abstract}

Keywords: Amino acid score, Entomophagy, Protein energy malnutrition, Dung beetle

\section{INTRODUCTION}

Protein is a major component of cell protoplasm and forms an integral part of tissues in animals including humans where it is required for repair of cells, growth and development. The basic units of all proteins are amino acids. Amino acids play a central role as the building blocks of proteins and they form metabolic intermediates as well as maintenance of health and vitality (Usydus et al., 2009). Eighteen amino acids found in human body are important in nutrition. Nine of these amino acids could be synthesized in sufficient amount in human body and are called nonessential amino acids. They include alanine, cysteine, glycine, aspartic acid, arginine, glutamic acid, proline, tyrosine and serine. The remaining nine, however cannot be synthesized by humans and hence must be supplied through dietary intake. They are referred to as essential amino acids. These include leucine, lysine, isoleucine, phenylalanine, tryptophan, methionine, histidine, valine and threonine. Occasionally cysteine and tyrosine may be referred to as semi essential amino acids because they are synthesized from methionine and phenylalanine respectively
(Boisen et al., 2000). Inability of the body to have sufficient amount of these essential amino acids could result in the degradation of body muscle protein (Usydus et al., 2009).

One major effect of protein deficiency in human nutrition is Protein Energy Malnutrition (PEM). This is an array of diseases which results in illness and death of millions of children worldwide due to absolute or relative deficiency of calories or protein in the diets (Muller and Krawinkel, 2005). Protein Energy Malnutrition is responsible for about $52 \%$ death of all under five children in Nigeria (Oyedeji, 2000) with $24 \%$ and $16 \%$ of all under five Nigerian population estimated to have suffered from moderate to severe malnutrition respectively (FAO/WHO/UNO, 1985). Persistence world's population growth coupled with limiting constraints of land, water and resources have posed a major challenge to providing adequate animal based protein worldwide (Yen, 2009). This has led to continuous call for the utilization of alternative sources of animal proteins such as edible insects in order to alleviate protein energy malnutrition especially in 
developing countries (Nuemann et al., 2002). However, this proposal has met with prejudices due to several cultural and sociological considerations surrounding human food preferences (Chang et al., 2010; Oriolowo, 2014). This is because many a time, human food choices are not made only by nutritional benefits but by sociological considerations (Vane-Wright, 1991; van Huis, 2003; Den Hartog et al., 2006).

The nutritive value of any protein food could be evaluated by considering its essential and nonessential amino acids, mutual proportion of specific essential amino acids; energy supplied which is essential for protein synthesis, amino acid score and predicted protein efficiency ratio (Usydus et al., 2009; Oluwaniyi et al., 2010). Quality of protein can also be evaluated by comparing its amino acids with a recognized standard protein relevant to all populations, especially on the basis of the limiting essential amino acids found in the food stuff. Limiting essential amino acid is the smallest of the amino acid found in the protein in comparison with standard protein. This significantly affects the net protein utilization which is the percentage of amino acids converted to protein against the amount amino acids supplied (Usydus et al., 2009). Moreover, quality of protein can be determined by assessing to what extent its amino acids could meet the Recommended Daily Intake (RDI) of various human age groups. This match between dietary supply and human protein need is vital to support the health and wellbeing of human population (FAO, 2013).

Based on the above criteria, the amino acid profiles of two conventional animal protein sources: Catfish (Clarias gariepinus) and Crayfish (Procambarus clarkii) were compared with a popular edible insect, dung beetle larva (Aphidius rufipes) in order to evaluate the nutritional quality of the latter.

\section{MATERIALS AND METHODS}

Collection and Preparation of Samples

Fresh samples of catfish (Clarias gariepinus) were purchased from a local fish farmer in Kontagora, Niger state, Nigeria. The sample was brought to the laboratory and thoroughly washed with clean water. The fish head was discarded and the remaining part cut into sizes. The cut sized fish was boiled in water at $100{ }^{\circ} \mathrm{C}$ for 10 minutes without adding any ingredient until the fish was well cooked and tender. All the bones were removed from the flesh and sundried.

Dung beetle larvae (Aphodius rufipes) were collected from cow dung from a Fulani settlement close to Kontagora, Nigeria. The larvae were brought to the laboratory and subsequently washed with water severally to remove soil particles and dung stains on them. The larvae abdominal regions were cut open with razor in order to remove excrement and undigested plant materials in them. The cut larvae were thoroughly washed with clean water once again before being boiled in hot water at $100{ }^{\circ} \mathrm{C}$ for 5 minutes. The boiled larvae were removed from the hot water and sundried for five days.

Crayfish (Procambarus clarkii) was purchased from new market in Kontagora, Nigeria. Dirt particles were handpicked from it washed and subsequently sundried. Dried samples of catfish, dung beetle larvae and crayfish were ground into fine particles separately using mortar and pestle. They were separately wrapped in aluminum foil and kept in separate plastic containers bearing their respective labels for easy identification before finally kept in a refrigerator prior to analysis.

\section{Determination of Amino Acids}

Amino acid analysis was done by ion exchange HPLC chromatography (Benitez, 1989), using the Applied PTH Amino Acid Analyzer (Model 120A). About $2 \mathrm{~g}$ of each of the samples was defatted using chloroform/methanol (2:1) (AOAC, 2006) and then hydrolyzed at $110{ }^{\circ} \mathrm{C}$ under nitrogen atmosphere for $22 \mathrm{hrs}$ with $6 \mathrm{M}$ hydrochloric acid. For tryptophan determination, $2 \mathrm{~g}$ of each of the samples was separately hydrolyzed with $4.2 \mathrm{M}$ sodium hydroxide for 22 hrs and were then neutralized to $\mathrm{pH} 7.0$ with $6 \mathrm{M}$ of hydrochloric acid. These hydrolysates were then injected into the amino acid analyzer for separation and characterization. Quantification was obtained by using external amino acid standards and the results were corrected for the recoveries. All analyses were conducted in 
triplicate for each sample.

Estimation of Quality of the Amino Acids The total amino acid (TAA), total essential amino acid (TEAA), total acid amino acid (TAAA), total sulphur amino acid (TSAA) and total aromatic amino acid $\left(\mathrm{TA}_{\mathrm{r}} \mathrm{AA}\right)$ were calculated. Predicted protein efficiency ratio (P-PER) was determined using the equation developed by Adeyeye (2009). P-PER $=-0.468+0.454$ (Leu) -0.105 (Tyr)

The amino acid score for essential amino acid was calculated according to FAO/WHO (1973)

$$
\mathrm{AA}_{\text {score }}=\mathrm{AAA}_{\mathrm{sp}} / \mathrm{AAA}_{\mathrm{Rp}}
$$

Where $\mathrm{AAA}_{\mathrm{sp}}$ is the amount of limited amino acid in the sample protein $(\mathrm{mg} / \mathrm{g})$ while $\mathrm{AAA}_{\mathrm{Rp}}$ is the amount of the same amino acid in the reference $\operatorname{protein}(\mathrm{mg} / \mathrm{g})$.

\section{RESULTS}

Table 1 shows the amino acids composition of catfish, dung beetle larva and crayfish. In all, 55\% of the total amino acids in three samples satisfied the required FAO/WHO standard. Essential amino acids: lysine, isoleucine, valine and threonine satisfied the FAO recommended daily allowance. Considering the criteria for comparing the amino acids in the samples, there were significant differences in total amino acids $\left(\mathrm{F}_{2,6}=\right.$ 219.9, ANOVA, LSD, $\mathrm{P}<0.05$ ), percentage essential amino acids $\left(\mathrm{F}_{2,6}=1095.4\right.$, ANOVA, LSD, $\mathrm{P}<0.05)$, essential amino acid score $\left(\mathrm{F}_{2,6}=\right.$ 2588.4, ANOVA, LSD, $\mathrm{P}<0.05)$, essential to nonessential amino acid ratio $\left(\mathrm{F}_{2,6}=236.7\right.$, ANOVA, LSD, $\mathrm{P}<0.05)$ and predicted protein efficiency ratio $\left(\mathrm{F}_{2,6}=1049.4\right.$, ANOVA, $\left.\mathrm{LSD}, \mathrm{P}<0.05\right)$. The essential amino acid scores were $68.2 \%$ in catfish, $200 \%$ in dung beetle larva and $80.9 \%$ in crayfish. Values which translated to the degree of protein being synthesized from the amino acid profiles of the samples. $66.7 \%$ of the essential amino acids in dung beetle larva satisfied FAO/WHO daily requirement for human. This is similar to the percentage recorded in crayfish, though this was lower than $77.7 \%$ recorded in catfish. Amino acids: tryptophan, histidine and threonine in dung beetle satisfied the FAO/WHO daily prescription as well as significantly higher than the values obtained for catfish and crayfish. Tryptophan was the limited essential amino acid in all the three samples; however its content in dung beetle satisfies the daily recommended allowance for humans. 
Table1: Amino acid Profile of Catfish, Dung beetle larva and Crayfish (g/100g protein

\begin{tabular}{|c|c|c|c|c|}
\hline Amino acid & Catfish & Dung beetle & Crayfish & $\begin{array}{l}* \mathrm{FAO} / \mathrm{WHO} \\
\text { Standard } \\
(\mathrm{RDA})\end{array}$ \\
\hline Leucine & $7.39 \pm 0.05$ & $5.95 \pm 0.02$ & $7.19 \pm 0.05$ & 6.60 \\
\hline Lysine & $8.46 \pm 0.04$ & $5.93 \pm 0.02$ & $6.98 \pm 0.04$ & 5.80 \\
\hline Isoleucine & $4.19 \pm 0.04$ & $3.08 \pm 0.03$ & $4.25 \pm 0.04$ & 2.80 \\
\hline Phenylalanine & $3.99 \pm 0.02$ & $3.72 \pm 0.02$ & $4.26 \pm 0.03$ & 6.30 \\
\hline Tryptophan & $0.75 \pm 0.03$ & $2.20 \pm 0.01$ & $0.89 \pm 0.03$ & 1.10 \\
\hline Valine & $5.04 \pm 0.03$ & $4.53 \pm 0.02$ & $4.51 \pm 0.02$ & 3.50 \\
\hline Methionine & $2.76 \pm 0.03$ & $2.23 \pm 0.02$ & $2.83 \pm 0.02$ & 2.50 \\
\hline Proline & $4.86 \pm 0.03$ & $4.68 \pm 0.01$ & $3.35 \pm 0.03$ & 9.13 \\
\hline Arginine & $6.62 \pm 0.02$ & $5.16 \pm 0.02$ & $7.75 \pm 0.03$ & 8.00 \\
\hline Tyrosine & $3.26 \pm 0.03$ & $5.33 \pm 0.02$ & $3.45 \pm 0.03$ & 6.30 \\
\hline Histidine & $2.17 \pm 0.02$ & $2.36 \pm 0.01$ & $1.79 \pm 0.02$ & 1.90 \\
\hline Cysteine & $0.85 \pm 0.03$ & $0.48 \pm 0.04$ & $1.25 \pm 0.03$ & 2.50 \\
\hline Alanine & $6.12 \pm 0.11$ & $4.85 \pm 0.02$ & $4.09 \pm 0.03$ & 3.11 \\
\hline Glutamic acid & $14.27 \pm 0.03$ & $12.19 \pm 0.01$ & $13.17 \pm 0.01$ & 5.60 \\
\hline Glycine & $8.01 \pm 0.03$ & $8.36 \pm 0.03$ & $7.54 \pm 0.03$ & 7.12 \\
\hline Threonine & $4.38 \pm 0.02$ & $6.16 \pm 0.05$ & $4.39 \pm 0.02$ & 3.40 \\
\hline Serine & $4.58 \pm 0.04$ & $4.75 \pm 0.02$ & $0.99 \pm 0.03$ & 9.93 \\
\hline Aspartic acid & $9.66 \pm 0.02$ & $6.29 \pm 0.02$ & $9.61 \pm 0.04$ & 5.30 \\
\hline$\sum$ TAA & $97.34^{\mathrm{a}}$ & $88.29^{\mathrm{b}}$ & $88.30^{\mathrm{b}}$ & 90.89 \\
\hline \% TEAA & $39.14(40.21 \%)^{\mathrm{a}}$ & $36.16(41.0 \%)^{\mathrm{b}}$ & $37.09(42.01 \%)^{\mathrm{c}}$ & \\
\hline \% TAAA & $23.93(24.58 \%)$ & $18.14(20.93 \%)$ & $22.78(25.80 \%)$ & \\
\hline \%TSAA & $3.61(3.71 \%)$ & $2.71(3.07 \%)$ & $4.08(4.62 \%)$ & \\
\hline$\%$ TArAA & $8.00(8.22 \%)$ & $11.25(12.74 \%)$ & $8.60(9.74 \%)$ & \\
\hline$\sum$ TEAA/ $\sum$ TNEAA & $0.67^{\mathrm{a}}$ & $0.69^{\mathrm{b}}$ & $0.72^{\mathrm{c}}$ & \\
\hline P-PER & $2.55^{\mathrm{a}}$ & $1.67^{\mathrm{b}}$ & $2.43^{c}$ & \\
\hline AA $_{\text {score }}$ & $0.68^{a}$ & $2.00^{\mathrm{b}}$ & $0.81^{\mathrm{c}}$ & \\
\hline
\end{tabular}

Values are mean of triplicate measurements

Mean carrying the same superscript are not significantly different (ANOVA, LSD, P<0.05)

*FAO/WHO (1991)

Table 2 compared the essential amino acids in catfish, dung beetle larva and crayfish with recommended daily intake of adult human. The values in brackets indicate the amount in grams to be consumed daily in order to meet the daily human need. The three samples showed excellent amino acid compositions which could readily satisfy the daily amino acid requirement of adult humans. For instance a daily consumption of about $38 \mathrm{~g}, 46 \mathrm{~g}$ and $41 \mathrm{~g}$ of catfish, dung beetle larva and crayfish respectively will adequately satisfy the daily amino acid requirement of an adult human. 
Table 2: Daily Recommended intake of Protein Samples which satisfy the body Amino acids Requirements

\begin{tabular}{lcclcl}
\hline \multicolumn{3}{c}{$*$ Recommended Daily Intake } & \multicolumn{3}{c}{$\mathrm{g} /$ 100g of protein } \\
\hline Amino acid & $\begin{array}{c}\mathrm{Mg} / \mathrm{Kg} \\
\text { body weight }\end{array}$ & $\begin{array}{c}\mathrm{g} / 70 \mathrm{~kg} \\
\text { body weight }\end{array}$ & Catfish & $\begin{array}{l}\text { Dung beetle } \\
\text { larva }\end{array}$ & Crayfish \\
\hline Leucine & 39.0 & 2.70 & $7.39(36.53)$ & $5.95(45.38)$ & $7.19(37.55)$ \\
Lysine & 30.0 & 2.10 & $8.46(24.82)$ & $5.93(35.41)$ & $6.98(30.09)$ \\
Isoleucine & 20.0 & 1.40 & $4.19(33.42)$ & $3.08(45.45)$ & $4.25(32.94)$ \\
Phe + Tyr & 25.0 & 1.75 & $7.27(24.07)$ & $9.05(19.34)$ & $7.71(22.70)$ \\
Theonine & 15.0 & 1.05 & $4.38(23.97)$ & $6.16(17.05)$ & $4.39(23.92)$ \\
Met + Cys & 15.0 & 1.05 & $3.60(29.16)$ & $2.73(38.46)$ & $4.08(25.73)$ \\
Valine & 26.0 & 1.82 & $5.04(36.16)$ & $4.53(40.18)$ & $4.51(40.36)$ \\
Tryptophan & 4.0 & 0.28 & $0.75(37.33)$ & $2.20(12.72)$ & $0.89(31.36)$ \\
Histidine & 10.0 & 0.70 & $2.17(32.26)$ & $2.36(29.66)$ & $1.79(39.11)$ \\
\hline$\sum$ Essential & 184.0 & 12.58 & & & \\
\hline
\end{tabular}

*RDI Standard WHO (2007)

Values in bold represent minimum recommended daily intake in grams of samples for adult humans

\section{DISCUSSION}

The percentage essential amino acid of catfish in this study was $40.2 \%$. This was similar to $42.5 \%$ reported for catfish by Osibona et al. (2009), while the ratio of essential to non-essential amino acids of the catfish was 0.67 . This was also lower than 0.74 reported by Osibona et al. (2009). The percentage essential amino acids in dung beetle larva in this study was $41 \%$ while essential to nonessential amino acids ratio was 0.69 . These were lower than $44.4 \%$ and 0.84 respectively reported for dung beetle larva (Paiko et al., 2012). The percentage essential amino acids obtained for crayfish was $42 \%$ while essential to non-essential amino acid ratio was 0.72 . These were also lower than $45 \%$ and 0.82 respectively reported by Ahmad et al. (2013) or $45.6 \%$ and 0.84 respectively reported by Nahid and Fayza (2009). This showed that dung beetle larva as well as the other two samples studied has excellent amino acid composition which satisfied the dietary recommendations of $39 \%$ for infants, $26 \%$ for children and $11 \%$ for adult humans (WHO/UNO, 1985). Moreover they also satisfy the recommended value of 0.6 of essential to nonessential amino acids for human diet (FAO/WHO, 1973).

The predicted protein efficiency ratio (P-PER) was lower in dung beetle larva compared to catfish and crayfish. The value of 1.67 obtained in dung beetle larva was similar to 1.60 and 1.64 respectively reported for two commonly consumed fishes in Nigeria, Clupea harengus and Scomber scombus fried in palm oil. It was however higher than a value of 1.35 reported for Tranchurus tranchurus (Oluwaniyi et al., 2010). Generally any protein diet of P-PER of at least 1.5 has been described as quality protein source (Friedman, 1996).

Dietary protein plays important roles in providing amino acids for biosynthesis of body proteins. It is therefore necessary that all the essential amino acids are supplied in appropriate amount for optimal protein synthesis (Alam et al., 2016). The study thus shows that the essential amino acids in dung beetle larva meet the requirement for maximum protein production. This is because a single amino acid deficiency will decrease protein synthesis and consequently growth to the extent that the animal will only grow to a point at which the supply of the deficient amino acid is exhausted. Such amino acid limiting the growth in this manner is referred to as limiting amino acid (Robinson and Li, 2015). In dung beetle larva, the essential amino acid tryptophan with a value of $2.20 \mathrm{~g} / 100 \mathrm{~g}$ of protein happens to be the least, but this value was higher than the recommended $1.10 \mathrm{~g} / 100 \mathrm{~g}$ of protein for human diet. This implied that dung beetle larva diet can enhance maximal level of protein synthesis unlike catfish 
and crayfish which are restricted to about $68.2 \%$ and $80.9 \%$ synthesis respectively.

The essential amino acids: lysine, isoleucine, tryptophan, valine, histidine and threonine are abundant in dung beetle larva. Lysine helps in the synthesis of carnitine, which converts fatty acids into energy and also plays an important role in the production of hormones, antibodies and enzymes. A deficiency in lysine could lead to niacin deficiency which causes a health condition called pellagra (Fagbenro et al., 2005). Histidine helps in the production of histamine, which takes part in allergic and inflammatory reactions. It plays a very important role in maintaining the osmoregulatory process and is related to energy production or is used in other metabolic pathways during certain emergencies or harsh conditions (Abe and Ohmama, 1987). Histidine is a component of haemoglobin and is important in prevention of rheumatoid, arthritis, ulcer and anaemia. A deficiency in histidine may cause hearing problem.

The amino acid, tryptophan plays an important role in the brain as a precursor of the neurotransmitter, serotonin, which has a major effect on the feeding behavior of animals (Mullen and Mortin, 1992). It also works as a relaxant, alleviate insomnia, prevent migraine, reduce anxiety and promote proper immune function. Isoleucine is necessary for haemoglobin formation, stabilizing and regulating blood sugar and energy (Osibona et al., 2009). Threonine is an important ingredient in the formation of bones, cartilages, hairs, teeth and nail. The consumption of phenylalanine helps to prevent mood swings, lethargy, sluggishness, feeling of anxiety and low morale. Leucine helps in physical performance, because it delays muscular deterioration and pain. Methionine aids in the production of sulphur, which is necessary for normal metabolism and it is also essential for the synthesis of haemoglobin and glutathione that fights against free radicals (Parcell, 2002; Akhirevbulu and Okonji, 2013). Generally, deficiency in any of these essential amino acids may hinder healing recovery process (Mat Jais et al., 1994). The fact that dung beetle larva is rich in lysine and threonine makes it a good supplement for their deficiency in food such as rice, maize, wheat and cassava which form commonly consumed staple food in developing countries including Nigeria.

\section{CONCLUSION}

The study showed that the amino acid composition of edible dung beetle larva compare favourably with those of catfish and crayfish. It has the potential to perform better as human source of food in terms of its amino acid score. This study once again confirms that many edible insects could be good sources of amino acids required in human diet. Therefore the prejudice against insects as human food in some countries and culture do not emanate from nutritional standpoint, but probably from some certain embedded sociological beliefs. Thus it is high time humans embraced entomophagy in the face of ever increasing population and dwindling animal protein sources.

\section{REFERENCES}

Abe, H., and Ohmama, S. 1987. "Effect of starvation, and seawater acclimation on the concentration and free $\mathrm{L}$ histidine and related dipeptides in the muscle of eel, rainbow trout and Japanese dace". Comparative Biochemistry and Physiololoy, 88B: 507-511

Adeyeye, E. I. 2009. Amino acid composition of three species of Nigerian fish: Clarias anguillaris, Oreochromis niloticus and Cynoglossus senegalensis. Food Chemistry, 113(1):43-46.

Ahmad, S. M. Birnin-Yauri, U. A., Bagudo B. U and Sahabi D. M. 2013. Comparative analysis on the nutritional values of crayfish and some insects. African Journal of Food Science and Technology, 4(1): 9-12

Akhirevbulu, C. J. and Okonji, V. A. 2013. Variation of proximate composition, amino acid and fatty acid profiles of parts of cultured Heterobranchus bidorsalis (Geoffrey Saint-Hilaire, 1809). Nigerian Journal of Agriculture, Food and Environment, 9(4):7-12

AOAC (Association of Official Analytical Chemicals) 2006. Official Method of Analysis of the AOAC (W. Horwitz Editor 
Eighteen Edition, Washington; D. C., AOAC.

Alam, S. M. D, Karim M.D.H, Chakrabortty A., Amim R. and Hasan S. 2016. Nutritional Characteristics of the long whiskered catfish Sperata aor: A commercially Important Freshwater Fish in Bangladesh. International Journal of Food Science and Nutritional Engineering, 6(1):1-8

Benitez, L. V. (1989). Amino Acid and fatty acid profiles in aquaculture nutrition studies, $\mathrm{p}$. 23- 35.in S.S. De Silva (ed.) Fish nutrition research in Asia. Proceedings of the third Asian fish nutrition network meeting. Asian fish Society Special Publication. 4, 166p. Asian Fisheries Society, Manila Philippines.

Boisen, S., Hvelplund, T., and Weisbjerg, M. R. 2000. Ideal amino acid profiles as a basis for feed protein evaluation. Livestock Production Science, 64: 239-251.

Chang, R. C. Y., Kivela, J., and Mak, A. H. N. 2010. Food preferences of Chinese tourists. Annals of Tourism Research, 37(4) : 9891011

Den Hartog, A. P, Van Stareren and Brouwer I. D 2006. Food habits and consumption in developing countries: Manual for field studies, Wagenningen Academic Publisher, 224p

Fagbenro, O. A., Akinbulumo, M. O., Adeparusi, O. E. and Raji, A. A. 2005. Flesh yield, waste yield, proximate and mineral composition of four commercial West African freshwater food fishes. Journal of Animal and Veterinary Advances, 4(10): 848-851.

FAO/WHO 1973. Energy and protein requirements. Technical report series no. 522. Geneva, Switzerland

FAO/WHO. 1991. Protein quality evaluation. Report of joint FAO/WHO expert consultation. FAO food and nutrition paper 51. Italy: Rome.

$\mathrm{FAO} / \mathrm{WHO} / \mathrm{UNO}$ 1985. Energy and proteins requirement. Report of Joint FAO/WHO/UNO Expert Consultation. WHO Technical Report Series 724. Geneva

FAO. 2013. FAO Forestry paper (7) Edible Insets
Future Prospects for Food and Feed Security. Food and agriculture organization of the centre nations. 17Pp.

Friedman, M. 1996. Nutritional value of protein from different food sources. A review. Journal of Agricultural and Food Chemistry, 44(1), 6-29.

Mat Jais, A. M, McCulloh R. and Croft K. 1994. Fatty acid and amino acid composition in haruan as a potential role in wound healing. General Pharmacology, 25: $947-$ 950.

Mullen, B.J. and Martin, R.J. (1992). The effect of dietary fat on diet selection may involve central serotonin. American. Journal of Physiolology, 263, R559-R563.

Muller, O. and Krawintel M. 2005. Malnutrition and health in developing countries. Canadian Medical Association Journal, 173(3): 279-286

Nahid, F. Z. and Fayza E. 2009. Study on chemical Quality and Nutrition Value of Fresh Water Cray Fish (Procambarus clarkii). Journal of the Arabian Aquaculture Society, 4 (1): 1-18

Nuemann, C, Harris D.M and Roger L. M. 2002. Contribution of animal source food in improving diet quality and function in children in developing world. Nutrition Research. 22:193-220

Oluwaniyi, O. O, Dosumu, O. O and Awolola G. V. 2010. Effect of local processing methods (boiling, frying and roasting) on the amino acid composition of four marine fishes commonly consumed in Nigeria. Food Chemistry, 123 (2010) 1000-1006

Oriolowo, O. B. 2014. Sociological Perspective of Entomophagy, Food insecurity and Poverty Alleviation in Nigeria. A paper presented at the $9^{\text {th }}$ Annual Conference Of Zoological Society of Nigeria (ZSN) Held at the Zoology Department University of Ibadan, Nigeria Between November $30^{\text {th }}-3^{\text {rd }}$ December

Osibona, A. O., Kusemiju, K., and Akande, G. R. 2009. Fatty acid composition and amino acid profile of two freshwater species, African Catfish (Clarias gariepinus) and Tilapia (Tilapia zilli). African Journal of 
Food, Agriculture, Nutrition and Development, 9(1), 608-621.

Oyedeji, G. A. 2000. Is it well with the Nigeria child? Obafemi Awolowo University Ile Ife, Nigeria. Inaugural Lecture Series 171

Paiko, Y. B., Dauda, B. E. N., Salau R. B., and Jacob J. O. 2012. Preliminary data on the nutritional potentials of the larvae of edible dung Beetle consumed in Paikoro Local Government Area of Niger State, Nigeria. Continental Journal of Food Science and Technology, 6 (2): 38 - 42,

Parcell, S. 2002. Sulfur in human nutrition and applications in medicine. Alternative Medicine. Review; 7 (1): 22-44.

Robinson, E. H. and Li M. H. 2015. A brief overview of catfish nutrition. Mississippi Agricultural and Forestry Experiment
Station Research report, 12(16): 1-7

Usydus, Z., Szlinder-Richert, J. and Adamczyk M. 2009. Protein quality and amino acid profiles of fish products available in Poland. Food Chemistry, 112: 139-145

van Huis, A. 2003. Insects as food in sub-Saharan Africa. Insect Science and its Application, 23(3): 163-185.

Vane-Wright, R. I. 1991. Why Not Eat Insects? Bulletin of Entomological Research, 81: $1-4$

WHO 2007. Protein and amino acid requirements in human nutrition: Report of a joint FAO/WHO/UNU expert consultation. WHO technical report series, Vol. 2012.

Yen, A. L 2009. Edible insects: Traditional knowledge or western phobia. Entomological Research, 39:289-298 